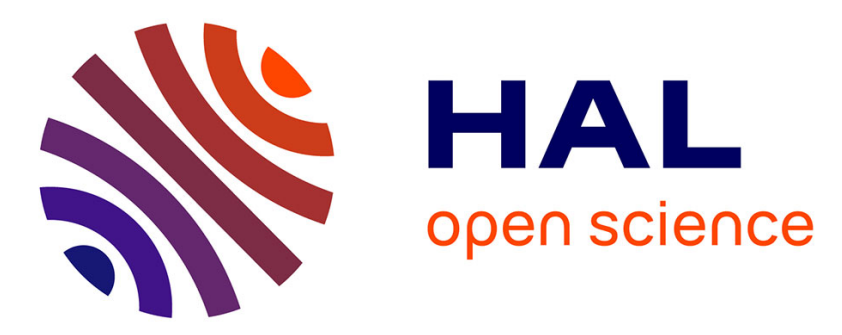

\title{
Robustness of Cell Disruption of Heavy Metal-Resistant Pseudomonas fluorescens BA3SM1 Isolates
}

\author{
Isabelle Poirier, N. Jean, Jean-Claude Guary, Martine Bertrand
}

\section{To cite this version:}

Isabelle Poirier, N. Jean, Jean-Claude Guary, Martine Bertrand. Robustness of Cell Disruption of Heavy Metal-Resistant Pseudomonas fluorescens BA3SM1 Isolates. Environmental Engineering Science, 2009, 26 (9), pp.1451-1457. 10.1089/ees.2009.0061 . hal-03244203

\section{HAL Id: hal-03244203 \\ https://hal.science/hal-03244203}

Submitted on 1 Jun 2021

HAL is a multi-disciplinary open access archive for the deposit and dissemination of scientific research documents, whether they are published or not. The documents may come from teaching and research institutions in France or abroad, or from public or private research centers.
L'archive ouverte pluridisciplinaire HAL, est destinée au dépôt et à la diffusion de documents scientifiques de niveau recherche, publiés ou non, émanant des établissements d'enseignement et de recherche français ou étrangers, des laboratoires publics ou privés. 


\title{
Short Communication
}

\section{The Robustness to Cell Disruption of the Heavy Metal-Resistant Pseudomonas fluorescens BA3SM1 Isolated from Tidal Flat Sediments}

\author{
Isabelle Poirier, ${ }^{1, *}$ Natacha Jean, ${ }^{2}$ Jean-Claude Guary, and Martine Bertrand ${ }^{1}$ \\ ${ }^{1}$ Equipe Microorganismes-Métaux-Toxicité, Laboratoire d'Etudes et de Recherches Marines, Institut National des Sciences \\ et Techniques de la Mer, Conservatoire National des Arts et Métiers, Cherbourg Cedex, France. \\ ${ }^{2}$ Equipe d'Ecologie et de Biologie des Milieux Aquatiques, Laboratoire des Processus de Transfert et des Echanges \\ en Environnement (EA 3819), Université du Sud Toulon-Var, La Garde Cedex, France.
}

\begin{abstract}
A bacterial strain (BA3SM1) was isolated from the tidal flat sediments collected in west of Cherbourg seaport (France). The biochemical characteristics and the partial 16S rDNA gene sequencing of isolate, BA3SM1, have allowed to identify it as Pseudomonas fluorescens. When cultivated, this strain exhibits a very high tolerance to metal contamination [minimal inhibitory concentration $=10 \mathrm{mM}(650 \mathrm{mg} / \mathrm{L})$ for zinc $(\mathrm{Zn}), 9 \mathrm{mM}(560 \mathrm{mg} / \mathrm{L})$ for copper $(\mathrm{Cu})$, and $3 \mathrm{mM}(350 \mathrm{mg} / \mathrm{L})$ for cadmium $(\mathrm{Cd})]$. To attempt to explain this high tolerance, future studies will be undertaken to analyze stress proteins produced by BA3SM1 in the presence of heavy metal excess. For this aim, several protein extraction procedures were tested, that is, biochemical, sonication, and high-pressure treatments. Our results show that BA3SM1 is very resistant to cell disruption, because an efficient protein release was only obtained with a drastic physical protocol: a treatment by a hypoosmotic shock followed by three passages through a French press at $159 \mathrm{MPa}$. This preliminary work is essential because it recommends a convenient protein extraction procedure to perform quality 2D-electrophoresis, from a tidal flat strain particularly resistant to heavy metals and to cell disruption. In further studies, proteomic analysis will allow to understand the resistance mechanisms developed by this strain to counteract heavy metal stresses. A better knowledge of these mechanisms will give us more information about the abilities of BA3SM1 to be used for bioremediation applications.
\end{abstract}

Key words: tidal flat bacterium; heavy metal resistance; cell disruption; protein extraction; high pressures; hypoosmotic shock; 2D-electrophoresis

\section{Introduction}

$\mathbf{I}^{\mathrm{s}}$

THE MARINE ENVIRONMENT, the tidal flat area is naturally submitted to wide variations of many parameters such as salinity, temperature, water turbulence, or light. Moreover, for the last decades, it has been severely affected by heavy metals resulting from the increase of human activities (Zhou et al., 2007a, 2007b). Atlhough various physicochemical processes have been developed for treating these pollutants, these approaches are often prohibitively expensive, nonspecific, disruptive to the sites, and nonadapted to vast ecosystems

${ }^{*}$ Corresponding author: Equipe Microorganismes-Métaux-Toxicité, Laboratoire d'Etudes et de Recherches Marines, Institut National des Sciences et Techniques de la Mer, Conservatoire National des Arts et Métiers, BP 324, F-50103 Cherbourg Cedex, France. Phone: +33 338873 34; Fax: +332338873 39; E-mail: isabelle.poirier@cnam.fr such as the tidal flat area (Srivastava and Majumder, 2008). In this specific environment, bioremediation with microorganisms seems to be an attractive alternative to conventional techniques. The application of micro-organisms for the remediation of heavy metals is a recent field of research in environmental engineering, and several studies have demonstrated the efficiency of metal removal by bacteria (Brar et al., 2006; Chen et al., 2007; Park et al., 2008; Srivastava and Majumder, 2008; Wasi et al., 2008). The microbioremediation focuses on the transformation of the metal, and its subsequent biosorption and biomineralization, which is the formation of insoluble metal precipitates due to interactions with microbial metabolic products (Brar et al., 2006; Park et al., 2008; Srivastava and Majumder, 2008; Wasi et al., 2008; Kazy et al., 2009). Among the bacterial species able to develop important adaptation strategies to survive in polluted habitats, there is Pseudomonas fluorescens. This species is present in various 
environments, and is known for its stress resistance (Stockwell and Loper, 2005). It is frequently found in contaminated area, and its survival strategies were described especially against pollutants like hydrocarbons, pesticides, or heavy metals (Sharma et al., 2006; Vasudevan et al., 2007; Wasi et al., 2008); nevertheless, no special focussing has been investigated on strains living in the tidal flat area. In this drastic environment, $P$. fluorescens strains have to adapt to numerous stresses to survive (Azam and Malfatti, 2007), and probably have to develop high-performance resistance mechanisms, making them interesting candidates for bioremediation studies.

Consequently, the objectives of this preliminary work were (1) to isolate a $P$. fluorescens strain from tidal flat sediments collected in a moderately metal-contaminated site to the west of Cherbourg seaport, (2) to study the ability of this strain to survive to heavy metal stresses, (3) and to compare the efficiency of different protein extraction protocols on this strain, to achieve quality 2D-electrophoresis. In further studies, proteomic analysis will be used to understand the mechanisms involved in the heavy metal resistance of this strain. A better understanding of these mechanisms will allow to determine if BA3SM1 is a promising agent for the bioremediation of polluted marine sediments.

\section{Materials and Methods}

\section{Bacterial strain isolation and growth conditions}

BA3SM1 was isolated from the top 2-cm layer of oxic marine sediments collected on the seashore at low tide in the $S^{t}$ Anne Bay (west of the Cherbourg seaport: $49^{\circ} 39 \mathrm{~N}-$ $001^{\circ} 40 \mathrm{~W}$, France). Long-term storage was performed at $-80^{\circ} \mathrm{C}$ in $25 \%$ glycerol. During the experimental period, the strain was stored at $+4^{\circ} \mathrm{C}$ on CFC agar plates and maintained by monthly subcultures. For all experiments, BA3SM1 was cultivated at $+22^{\circ} \mathrm{C}$ in $100 \mathrm{~mL}$ of nutrient broth containing $1 \%$ $(\mathrm{w} / \mathrm{v})$ tryptone, $0.5 \%(\mathrm{w} / \mathrm{v})$ meat extract, $0.5 \%(\mathrm{w} / \mathrm{v}) \mathrm{NaCl}$ (Biokar Diagnostics, Beauvais, France) $(\mathrm{pH}=7.4)$. Cultures were inoculated with $1 \mathrm{~mL}$ of bacterial suspension from a 24h-old preculture. All samples were harvested at the end of the exponential growth phase $(15 \mathrm{~h})$, so that the bacterial concentration was always $2.10^{8}$ cells $/ \mathrm{mL}$, which corresponds to 0.330 absorbance units at $\lambda=600 \mathrm{~nm}$.

\section{Identification and characterization of bacteria}

Identification of the BA3SM1 strain was carried out by performing Gram staining, mobility, shape, oxidase, catalase, and other complementary biochemical tests using API 20NE system (bioMérieux, France). To confirm the identification of the bacterium, a partial 16S rDNA gene sequencing was performed (Genoscreen, France).

\section{Minimal inhibitory concentration (MIC) determination}

MICs of the strain BA3SM1 were determined in the media described above, supplemented with increasing concentrations of a given metal $\left(\mathrm{ZnCl}_{2}, \mathrm{CuCl}_{2}, \mathrm{CdCl}_{2}\right)$. The cultures were incubated for up to 30 days, and growth was monitored by absorbance measurements at $600 \mathrm{~nm}$. MIC is generally defined as the lowest metal concentration for which the growth is inhibited.

\section{Preparation of protein extracts with different extraction procedures}

Biochemical treatments. A cell culture $(100 \mathrm{~mL})$ was centrifugated at $10,000 \times g$ for $10 \mathrm{~min}$. The pellet was resuspended in a lysis buffer $(0.1 \mathrm{M}$ Tris- $\mathrm{HCl}, \mathrm{pH} 7.5)$ containing either $0.1,0.5$, or $1.0 \%$ lysozyme; or $0.5 \%$ lysozyme and $1.5 \%$ Triton X-100; or $0.5 \%$ lysozyme and $1.5 \%$ sodium dodecyl sulphate (SDS). The mixture was incubated for $30 \mathrm{~min}$ or $1 \mathrm{~h}$ at $+4^{\circ} \mathrm{C}$ to inhibit the protease activity, with occasional stirring. At the end of the incubation, cells were harvested by centrifugation for $10 \mathrm{~min}$ at $10,000 \times g$ to remove enzymatic and chemical agents. The pellet was then resuspended in $10 \mathrm{~mL}$ of ultrapure water to achieve a hypoosmotic shock to induce the intracellular protein release.

Sonication. A cell culture $(100 \mathrm{~mL})$ was centrifugated at $10,000 \times g$ for $10 \mathrm{~min}$. The pellet was washed twice and resuspended in $10 \mathrm{~mL}$ of ultrapure water (hypoosmotic shock). Cells were disrupted by sonication (sonicator ultrasonic processor XL, Misonix, Farmingdale, NY) using a microtip (maximal acoustic power: $168 \mathrm{~W}$ ) in an ice-water bath. Sonication was undertaken at a frequency of $20 \mathrm{kHz}$. Several acoustic powers $(30,50,100$, and $125 \mathrm{~W})$ and sonication times $(8,15$, and $30 \mathrm{~min})$ were tested with 2 -s on $/ 2$-s off cycles. An experiment was also carried out with $10 \mathrm{~mL}$ of Tris EDTA/phenylmehtylsulfonyl fluroide (TE/PMSF) buffer $(10 \mathrm{mM}$ Tris- $\mathrm{HCl}, 1 \mathrm{mM}$ ethylenediamine tetraacetic acid (EDTA), 0.1 mM PMSF, pH 7.5) instead of ultrapure water (Sauer and Camper, 2001; Sonawane et al., 2003).

Freezing-thawing cycles/sonication. A cell culture $(100 \mathrm{~mL})$ was centrifugated at $10,000 \times g$ for $10 \mathrm{~min}$. The pellet was washed twice and resuspended in $10 \mathrm{~mL}$ of TE/PMSF buffer. The sample was submitted to one or five freeze-thaw cycles. Then, cells were disrupted by sonication (sonicator ultrasonic processor $\mathrm{XL}$, Misonix) using a microtip in an icewater bath at $20 \mathrm{kHz}, 30 \mathrm{~W}$ during $10 \mathrm{~min}$, with 2-s on/2-s off cycles.

High pressures. The culture $(100 \mathrm{~mL})$ was centrifugated at $10,000 \times g$ for $10 \mathrm{~min}$. The pellet was washed twice and resuspended in $10 \mathrm{~mL}$ of ultrapure water (hypoosmotic shock). Cells were disrupted through a precooled French press cell (French pressure cell $40 \mathrm{~K}$, Thermo IEC, Needham Heights, MA). The influence of the number of passages (one to five passages) and the applied pressure (120 MPa or $159 \mathrm{MPa})$ were tested in relation to protein release.

An experiment was also carried out with $10 \mathrm{~mL}$ of TE/PMSF instead of ultrapure water.

Protein concentration measurement. After each treatment, samples were centrifugated for $10 \mathrm{~min}$ at $10,000 \times \mathrm{g}$ at $+4^{\circ} \mathrm{C}$ to pellet cell debris. Protein concentration in the supernatant was determined according to Bradford (1976). All the measurements were carried out in duplicate. The detection limit was $0.005 \mathrm{mg} / \mathrm{mL}$ (Bradford, 1976).

Purification and concentration of the protein extracts. All protein extracts were purified and concentrated five times with a centrifugal concentrator $(10 \mathrm{kDa}$ cutoff size, Amicon Ultra-4 Millipore, Bedford, MA); and stored at $-80^{\circ} \mathrm{C}$ until analysis. 


\section{THE ROBUSTNESS OF A TIDAL FLAT BACTERIUM}

\section{SDS-PAGE analysis}

Samples with a sufficient protein concentration (higher than $3 \mathrm{mg} / \mathrm{mL}$ ) were separated by $12.5 \%$ SDS-PAGE (Laemmli, 1970). Electrophoresis was performed during $90 \mathrm{~min}$ at $100 \mathrm{~V}$ using the Mini Protean 3 apparatus (Bio-Rad, Hercules, CA). Proteins were then visualized by staining with Bio-Safe Coomassie Blue (Bio-Rad).

\section{$2 D$-electrophoresis tests}

For isoelectric focusing (IEF), 250 or $500 \mu \mathrm{g}$ proteins were solubilized in a rehydration buffer containing $8 \mathrm{M}$ urea, $4 \%$ (w/v) 3-[3[cholamidoproply)diamethylammomio]-1]propansulfonate (CHAPS), $20 \mathrm{mM}$ DTT, $0.2 \%$ Bio-Lyte 3-10 and $0.001 \%(\mathrm{w} / \mathrm{v})$ bromophenol blue. After active rehydration at $50 \mathrm{~V}$ for $17 \mathrm{~h}$ under paraffin oil, $17 \mathrm{~cm}$-long immobilized $\mathrm{pH}$ gradient (IPG) strips ( $\mathrm{pH} 3-10$ or $\mathrm{pH} \mathrm{4-7,} \mathrm{Bio-Rad)} \mathrm{were}$ submitted to IEF (Protean IEF Cell, Bio-Rad) with the following voltage/time process: $150 \mathrm{~V}$ for $1 \mathrm{~h}, 350 \mathrm{~V}$ for $15 \mathrm{~min}$, $750 \mathrm{~V}$ for $45 \mathrm{~min}, 1,500 \mathrm{~V}$ for $1 \mathrm{~h}$, and 3,500 V for $18 \mathrm{~h}$ (adapted from Vilain et al., 2004). All steps were performed with rapid ramping. After IEF separation, strips were consecutively incubated in equilibration buffers $\mathrm{A}$ and $\mathrm{B}$ for $15 \mathrm{~min}[50 \mathrm{mM}$ Tris/ $\mathrm{HCl}, \mathrm{pH} 8.8,6 \mathrm{M}$ urea, $30 \%$ (v/v) glycerol, $2 \%$ (w/v) SDS, with $65 \mathrm{mM}$ DTT (solution A) or $135 \mathrm{mM}$ iodoacetamide (solution $\mathrm{B})]$. In the second dimension, proteins were separated by SDS-PAGE on $17 \times 17-\mathrm{cm}$ gels containing $12.5 \%$ acrylamide according to Laemmli (1970). The gels were run in a Protean II cell (Bio-Rad) at $+4^{\circ} \mathrm{C}(1 \mathrm{~h}$ at $25 \mathrm{~V}$, then at $200 \mathrm{~V}$ until the bromophenol blue dye reached $5 \mathrm{~mm}$ from the bottom of the gel). Proteins were visualized by gel staining with Bio-Safe
Coomassie Blue (Bio-Rad). The gels were then analyzed using the PD-Quest software 7.3.0 version (Bio-Rad).

\section{Results}

\section{Identification and characterization of bacteria}

The API 20NE system has identified BA3SM1 to be Pseudomonas fluorescens. This identification was confirmed by the partial 16S rDNA gene sequencing.

\section{MIC determination}

The MIC values for the three heavy metals tested are $10 \mathrm{mM}$ $(650 \mathrm{mg} / \mathrm{L})$ for zinc $(\mathrm{Zn}), 9 \mathrm{mM}(560 \mathrm{mg} / \mathrm{L})$ for copper $(\mathrm{Cu})$, and $3 \mathrm{mM}(350 \mathrm{mg} / \mathrm{L})$ for cadmium $(\mathrm{Cd})$. As a result, BA3SM1 is metal resistant.

\section{Influence of the extraction procedure on the protein} concentration of extracts and SDS-PAGE analysis

The concentrations of the protein extracts are indicated for each protocol in Table 1.

Biochemical treatments. With the use of lysozyme only, during $30 \mathrm{~min}$ at $+4^{\circ} \mathrm{C}$, the protein concentration is lower than $1 \mathrm{mg} / \mathrm{mL}$ for the three enzyme concentrations tested $(0.1,0.5$, and $1.0 \%)$. At a fixed concentration $(0.5 \%)$ and for a longer action time $(1 \mathrm{~h})$, protein concentration increased at least threefold, to finally reach $3.15 \mathrm{mg} / \mathrm{mL}$. When a detergent like Triton X-100 or SDS was used in combination with the lysozyme, protein extraction proved to be more efficient, a maximal protein concentration of $8.50 \mathrm{mg} / \mathrm{mL}$ being reached after

Table 1. Protein Concentration of Final Extracts Obtained with the Different Extraction Methods

\begin{tabular}{llc}
\hline \multicolumn{1}{c}{ Protein extraction method } & $\begin{array}{c}\text { Protein concentration } \\
\text { after }\end{array}$ \\
\hline Biochemicafiltration $(\mathrm{mg} / \mathrm{mL})$
\end{tabular}

${ }^{a}$ These protein concentration values are overestimated due to lysozyme, as revealed by sodium dodecyl sulphate-polyacrylamide gel electrophoresis (SDS-PAGE).

TE/PMSF, Tris EDTA/phenylmethylsulfonyl fluoride. 
SDS treatment. The SDS-PAGE profiles of protein extracts

with a concentration higher than $3 \mathrm{mg} / \mathrm{mL}$ are shown in Fig. (lanes 1-3). The sample protein bands are hardly visible; only one band clearly appears on the gel, corresponding to the lysozyme $(14.4 \mathrm{kDa})$. This result reveals that the residual presence of lysozyme and detergents in the extracts has disturbed the protein measurement by the Bradford method and has contributed to an important overestimation of the amount of extracted proteins. In these three extracts, the amount of bacterial proteins was so low that no clear bands appeared on the gel. Taking these results into account, P. fluorescens BA3SM1 seems to be particularly insensitive toward biochemical treatments.

Sonication. Sonication applied in ultrapure water, or in TE/PMSF buffer with or without freeze-thaw cycles, proved to be inefficient to achieve a substantial release of soluble proteins from the $P$. fluorescens BA3SM1. Consequently, this strain is an example of a special biological material for which cell disruption proved to be particularly difficult.

High pressures. At $120 \mathrm{MPa}$ in ultrapure water, three passages have been required to reach a maximal protein concentration $(3.55 \mathrm{mg} / \mathrm{mL})$. For a higher pressure of $159 \mathrm{MPa}$, this value increased twofold to reach $8.00 \mathrm{mg} / \mathrm{mL}$. When passages in the French press were carried out in TE/PMSF buffer instead of ultrapure water, protein extract concentrations were slightly lower $(2.5 \mathrm{mg} / \mathrm{mL}$ instead of $3.55 \mathrm{mg} / \mathrm{mL}$ ). So, for BA3SM1, an osmotic shock combinated with three passages at $159 \mathrm{MPa}$ were necessary to obtain a sufficient protein release that confirms its high resistance to disruption. The SDS-PAGE profiles of protein extracts with a concentration higher than $3 \mathrm{mg} / \mathrm{mL}$ are shown in Fig. 1 (lanes $4-5)$. Numerous well-separated bands are visible. Both profiles are similar whatever the applied pressure (120 MPa for lane 4 and $159 \mathrm{MPa}$ for lane 5). Taking this result into account, we have decided to extract proteins with the French press (three passages at $159 \mathrm{MPa}$ in ultrapure water) to achieve the first 2D-electrophoresis tests.

2D-electrophoresis tests. The results of the protein separation by 2D-electrophoresis are shown in Fig. 2.

When the 2D-electrophoresis was started with $250 \mu \mathrm{g}$ proteins and with $\mathrm{pH} 3-10$ gradient strips (Fig. 2A), poorly defined spots were observed, mainly located at low $\mathrm{pH}_{\mathrm{i}}$ values. The PD-Quest software detected only $340 \pm 31$ spots $(n=4)$; moreover, many horizontal streaks are present. Consequently, this first result is unexploitable. When the 2Delectrophoresis was performed with $500 \mu \mathrm{g}$ proteins and using strips with a $\mathrm{pH} \mathrm{4-7}$ gradient (Fig. 2B), spots were well defined and distributed on the totality of the gel surface. In these new conditions, the PD-Quest software detected $1238 \pm 31$ spots $(n=4)$.

\section{Discussion}

$P$. fluorescens BA3SM1 has shown a high level of resistance to all the metals tested, because continued growth was observed in the presence of high metal concentrations. The MIC values indicated that this strain was sensitive to heavy metals in the following order: $\mathrm{Cd}>\mathrm{Cu}>\mathrm{Zn}$. A relatively diverse range of Pseudomonas MICs have been reported for $\mathrm{Cu}, \mathrm{Cd}$, or $\mathrm{Zn}$. For $\mathrm{Cu}$, Teitzel and Parsek (2003) found an MIC of $127 \mathrm{mg} / \mathrm{L}$ for Pseudomonas aeruginosa, and Chen et al. (2006) $190 \mathrm{mg} / \mathrm{L}$ for Pseudomonas putida, whereas Bender and
FIG. 1. SDS-PAGE profiles of Pseudomonas fluorescens proteins extracted by various protocols. Proteins $(50 \mu \mathrm{g})$ were loaded in each well.

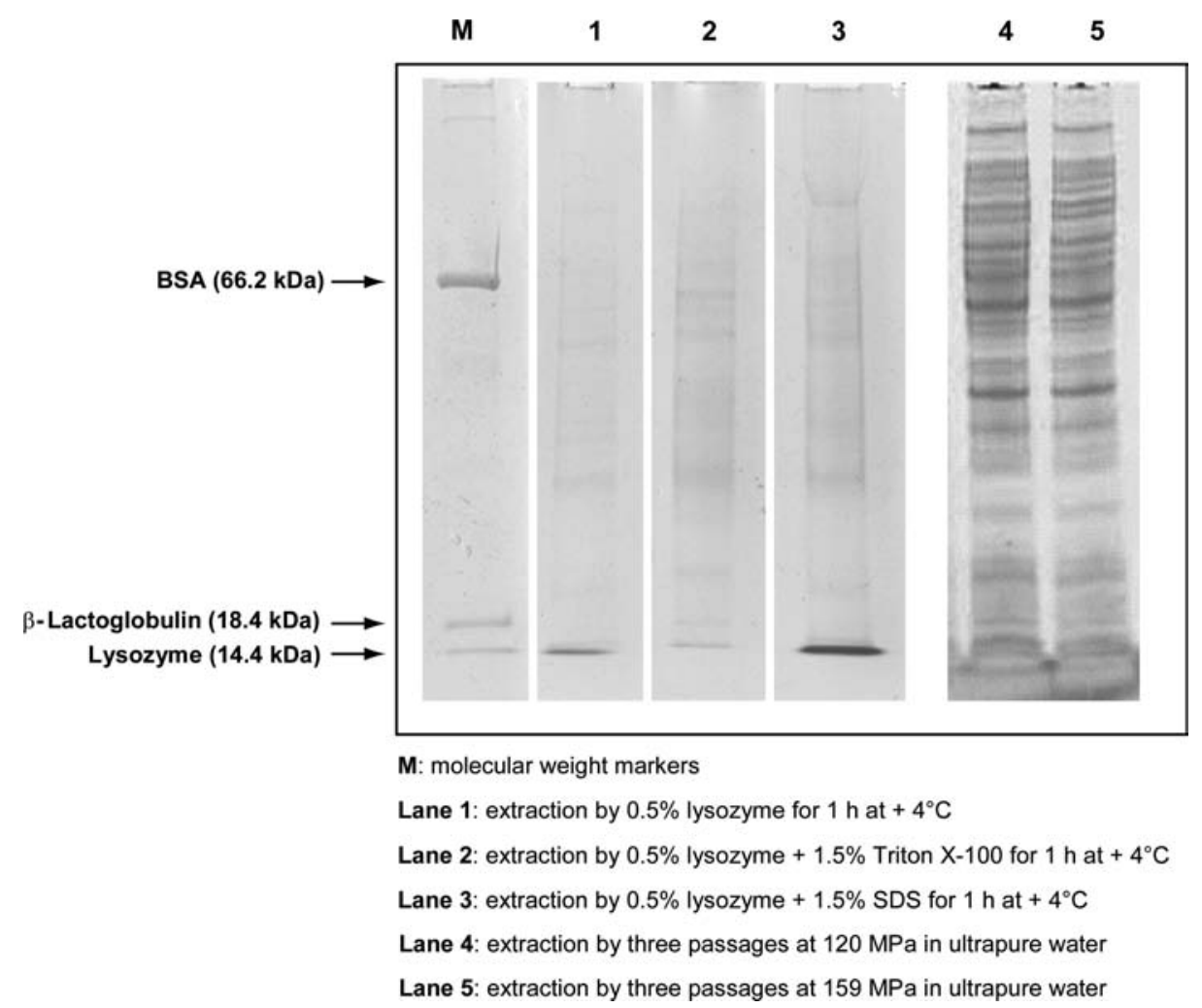




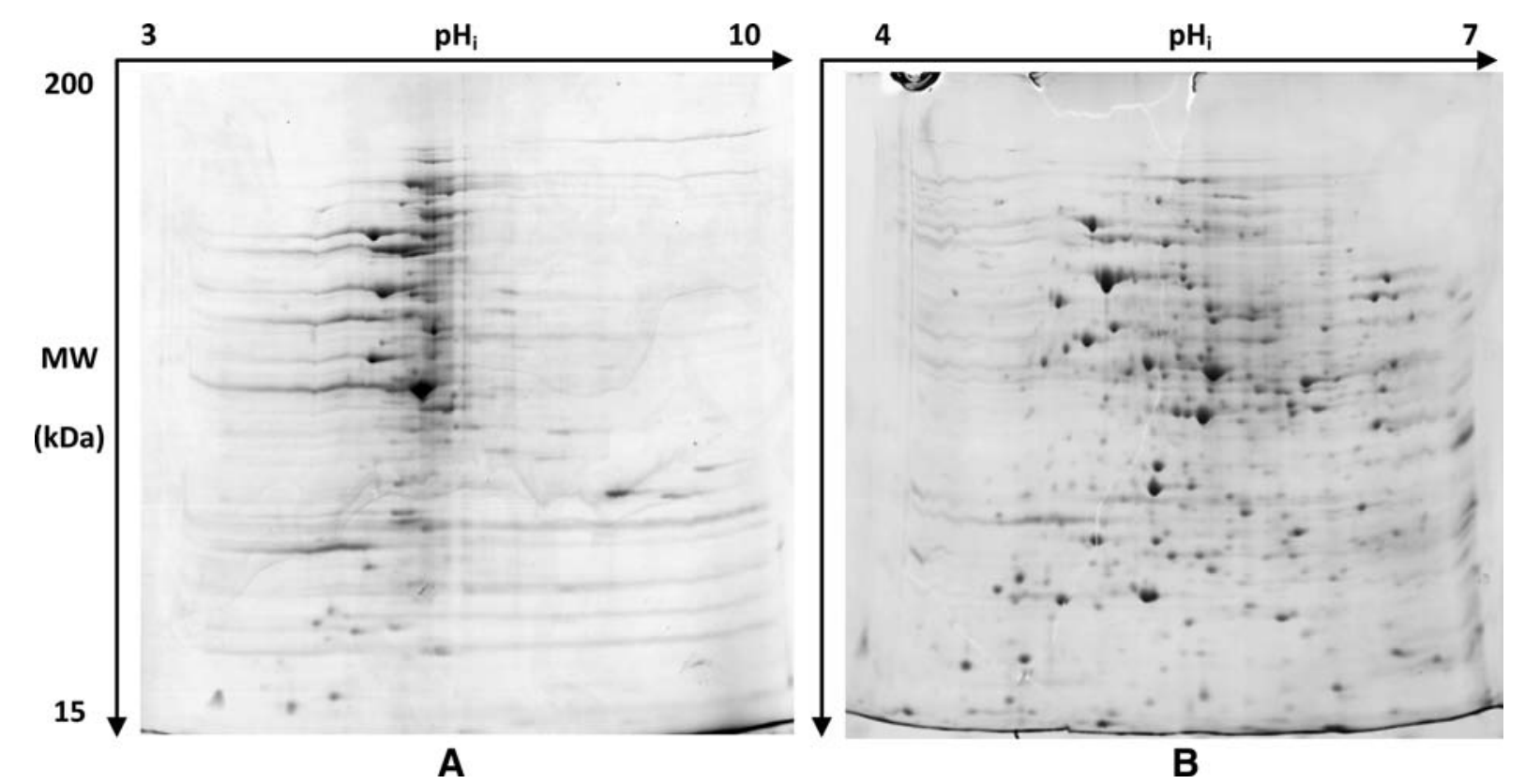

FIG. 2. 2D-electrophoresis gels of $P$. fluorescens hydrosoluble proteins. The protein extraction was performed by combination of a hypoosmotic shock and high pressures (three passages in the French Press at $159 \mathrm{MPa})$. (A) Proteins $(250 \mu \mathrm{g})$, strips with a pH 3-10 gradient, and Coomassie blue staining were used. (B) Proteins (500 $\mu \mathrm{g}$ ), strips with a pH 4-7 gradient, and Coomassie blue staining were used.

Cooksey (1986) obtained a value of $6.35 \mathrm{mg} / \mathrm{L}$ for Pseudomonas syringae, and Tom-Petersen et al. (2001) $3 \mathrm{mg} / \mathrm{L}$ for Pseudomonas fluorescens. For Zn, MICs range between $50 \mathrm{mg} / \mathrm{L}$ for Pseudomonas sp. (Malik and Jaiswal, 2000) and 3,139 mg/L for Pseudomonas aeruginosa (De Vincente et al., 1990). For Cd, some Pseudomonas strains were incapable of growth at $\mathrm{Cd}$ concentrations above $1.1 \mathrm{mg} / \mathrm{L}$ (Zawadzka et al., 2007), whereas other strains could tolerate concentrations as high as $1,000 \mathrm{mg} / \mathrm{L}$ (Pseudomonas sp.: Malik and Jaiswal, 2000; Pseudomonas putida: $\mathrm{Hu}$ and Zhao, 2007). By comparing our results with those quoted previously, it appears that our Pseudomonas strain presents a high metal resistance.

Literature often reports sonication and biochemical lysis as means to disrupt Gram-negative cells and to release intracellular hydrosoluble biomolecules (Willcox et al., 2001; Hanoulle et al., 2004; Sharma et al., 2006; Kabayashi et al., 2007; Bar et al., 2007), but these treatments were inefficient to obtain a substantial release of soluble proteins from BA3SM1. In our study, the lysozyme activity is surely low at $+4^{\circ} \mathrm{C}$ compared to the one at its optimal temperature; nevertheless, after an action time of $1 \mathrm{~h}$, the enzyme should have been efficient, as it was demonstrated by other authors (Hanoulle et al., 2004; Kobayashi et al., 2007). Moreover, the presence of lysozyme in extracts, as revealed by SDS-PAGE, contributes to an important overestimation of the protein concentration, making impossible the achievement of an electrophoresis in good conditions. Concerning the sonication, all the tested treatments were totally inefficient for our strain. However, sonication conditions similar to ours were applied successfully in several Pseudomonas proteomic studies ( $P$. aeruginosa: Vilain et al., 2004; P. putida: Sauer and Camper, 2001). Consequently, BA3SM1 is an example of a special biological material for which cell disruption proved to be particularly difficult. The strong resistance of this strain could be due to the special robustness of its envelope resulting from adaptations to survive in the tidal flat area. Indeed, this zone is submitted to important physicochemical changes and to an accumulation of pollutants, and then it is generally considered as a stressfull environment for organisms (Zhou et al., 2007a, 2007b). Consequently, the bacteria living in this specific environment must adapt to numerous stresses (Azam and Malfatti, 2007) by controlling, for example, the biochemical and biophysical properties of their envelope, and/or by producing exopolymers (Beney and Gervais, 2001; Nikolaev, 2004; MancusoNichols et al., 2005; Baysse and O'Gara, 2007; Noghabi et al., 2007; Leuko et al., 2008; Morbach and Krämer, 2008; Saravanan and Jayachandran, 2008; Zhang and Rock, 2008). Such mechanisms, which are commonly mentionned as adaptation strategies by bateria, could explain the cell wall robustness and the high metal resistance of BA3SM1. Indeed, the tolerance to metals could be a consequence of the biosorption process, a passive phenomenon, which depends totally on physicochemical characteristics of cell wall (Wasi et al., 2008) and consequently, which is affected by environmental factors (Noghabi et al., 2007). In the tidal flat zone, bacteria are exposed to a wide range of stress-inducing fluctuating conditions and probably develop envelope features which facilitate the metal biosorption. Future experiments must be carried out to verify these hypotheses and to explain why BA3SM1 is so hard to disrupt by regular techniques.

Another resistance mechanism allowing survival of tidal flat bacteria in the presence of high concentrations of heavy metals could be the synthesis of specific proteins, as it was demonstrated in other environments (Sharma et al., 2006; Bar et al., 2007; Henne et al., 2009). To verify this hypothesis by proteomic experiments, it is necessary to have concentrated bacterial protein extracts (at least $5 \mathrm{mg} / \mathrm{mL}$ ). This condition is essential to achieve 2D-dimensional electrophoresis and further protein staining with Coomassie blue, which is a reliable dye for a subsequent mass spectrometry analysis 
(Lauder et al., 2001). The first 2D-electrophoresis tests, gave satisfactory results, when $500 \mu$ g proteins and $\mathrm{pH} 4-7$ gradient strips were used. These experimental conditions agree with the ones described by several authors for Pseudomonas proteomic studies (Cases et al., 2001; Wehmhöner et al., 2003; Sharma et al., 2006). Qualitatively, spots are well defined, and distributed on the totality of the gel surface. Quantitatively, the PD-Quest software has detected $1238 \pm 31$ spots $(n=4)$, which is relatively close to the results mentioned in the literature (Sauer and Camper, 2001) for the Pseudomonas genus. As a result, this present work appears to be determinant because it allows us to get highly concentrated protein extracts allowing the achievement of high-quality 2D-electroploresis. In future studies, protein maps will be used to identify specific stress proteins implied in the heavy metal resistance of a P. fluorescens strain living in the tidal flat sediments.

\section{Conclusion}

It can be concluded based on this study that:

1. P. fluorescens BA3SM1 isolated from the tidal flat sediments is heavy metal-resistant. So, it represents a very interesting model of study to characterize the effects of metallic stresses on the bacterial proteome. Moreover, this organism is a very interesting candidate for bioremediation studies.

2. BA3SM1 is particularly resistant toward cell disruption, and this robustness could be due to specific biochemical and biophysical properties of its envelope. It would be interesting to attempt to explain whether this robustness is due to particular envelop properties or/and exopolymers production which could facilitate external metal biosorption.

3. This preliminary work is essential because it suggests a convenient protein extraction procedure to achieve quality 2D-electrophoresis in further studies. Later on, proteomics will allow us to have a better knowledge of the resistance mechanisms developed by BA3SM1 to survive to heavy metal stresses.

\section{Acknowledgments}

The authors warmly thank Gregory Berk for his corrections concerning the English language. This work was financially supported by the Syndicat mixte du Cotentin, the Conseil Régional de Basse-Normandie, and the Direction de la Recherche du Ministère de l'Education Nationale, de l'Enseignement Supérieur et de la Recherche.

\section{Author Disclosure Statement}

The authors declare that no competing financial interests exist.

\section{References}

Azam, F., and Malfatti, F. (2007). Microbial structuring of marine ecosystems. Nat. Rev. Microbiol. 5, 782.

Bar, C., Patil, R., Doshi, J., Kulkarni, M.J., and Gade, W.N. (2007). Characterization of the proteins of bacterial strain isolated from contaminated site involved in heavy metal resistance-A proteomic approach. J. Biotechnol. 128, 444.
Baysse, C., and O'Gara, F. (2007). Role of membrane structure during stress signalling and adaptation in Pseudomonas. In J.-L. Ramos and A. Filloux, Eds., Pseudomonas: A Model System in Biology. Berlin: Springer, p. 193.

Bender, C.L., and Cooksey, D.A. (1986). Indigenous plasmids in Pseudomonas syringae pv. tomato: Conjugative transfer and role in copper resistance. J. Bacteriol. 165, 534.

Beney, L., and Gervais, P. (2001). Influence of the fluidity of the membrane on the response of microorganisms to environmental stresses. Appl. Microbiol. Biot. 57, 34.

Bradford, M.M. (1976). A rapid and sensitive method for the quantification of microgram quantities of protein utilizing the principle of protein-dye binding. Anal. Biochem. 72, 248.

Brar, S.K., Verma, M., Surampalli, R.Y., Misra, K., Tyagi, R.D., Meunier, N., and Blais, J.F. (2006). Bioremediation of hazardous wastes: A review. Pract. Period. Hazard. Toxic Radioact. Waste Manage. 10, 59.

Cases, I., Lopez, J.A., Albar, J.P., and De Lorenzo, V. (2001). Evidence of multiple regulatory functions for the PtsN (IIA ${ }^{\mathrm{Ntr}}$ ) protein of Pseudomonas putida. J. Bacteriol. 183, 1032.

Chen, X.C., Shi, J.Y., Chen, Y.X., Xu, X.H., Xu, S.Y., and Wang, Y.P. (2006). Tolerance and biosorption of copper and zinc by Pseudomonas putida CZ1 isolated from metal-polluted soil. Can . J. Microbiol. 52, 308.

Chen, X.C., Shi, J.Y., Chen, Y.X., Xu, X.H., Chen, L.T., Wang, H., and Hu, T.D. (2007). Determination of copper binding in Pseudomonas putida CZ1 by chemical modifications and X-ray absorption spectroscopy. Appl. Microbiol. Biotechnol. 74, 881.

De Vincente, A.M., Aviles, J.C., Codina, J.C., Borrego, J.J., and Romero, P. (1990). Resistance to antibiotics and heavy metals of Pseudomonas aeruginosa isolated from natural waters. J. Appl. Bacteriol. 68, 625.

Hanoulle, X., Rollet, E., Clantin, B., Landrieu, I., ÖdbergFerragut, C., Lippens, G., Bohin, J-P., and Villeret, V. (2004). Structural analysis of Escherichia coli OpgG, a protein required for the biosynthesis of osmoregulated periplasmic glucans. J. Mol. Biol. 342, 195.

Henne, K.L., Turse, J.E., Nicora, C.D., Lipton, M.S., Tollaksen, S.L., Lindberg, C., Babnigg, G., Giometti, C.S., Nakatsu, C.H., Thompson, D.K., et al. (2009). Global proteomic analysis of the chromate response in Arthrobacter sp. Strain FB24. J. Proteome Res. (in press).

$\mathrm{Hu}$, N., and Zhao, B. (2007). Key genes involved in heavy-metal resistance in Pseudomonas putida CD2. FEMS Microbiol. Lett. 267, 17.

Kazy, S.K., D'Souza, S.F., and Sar, P. (2009). Uranium and thorium sequestration by a Pseudomonas sp.: Mechanism and chemical characterization. J. Hazard. Mater. 163, 65.

Kobayashi, Y., Ishizaki, S., Shimakura, K., Nagashima, Y., and Shiomi, K. (2007). Molecular cloning and expression of two new allergens from Anisakis simplex. Parasitol. Res. 100, 1233.

Laemmli, U.K. (1970). Cleavage of structural proteins during the assembly of the head of bacteriophage T4. Nature 15, 680 .

Lauder, W.M., Carroll, J.A., Dufield, D.R., Kiesel, J.R., Radabaugh, M.R., and Malone, J.P. (2001). Mass spectrometry compatibility of two-dimensional gel proteins stains. Electrophoresis $22,906$.

Leuko, S., Goh, F., Ibanez-Peral, R., Burns, B.P., Walter, M.R., and Neilan, B.A. (2008). Lysis efficiency of standard DNA extraction methods for Halococcus spp. in an organic rich environment. Extremophiles 12, 301.

Malik, A., and Jaiswal, R. (2000). Metal resistance in Pseudomonas strains isolated from soil treated with industrial wastewater. World J. Microb. Biot. 16, 177. 
Mancuso-Nichols, C., Garon-Lardiere, S., Bowman, J.P., Nichols, P.D., Gibson, J.A.E., and Guezennec, J. (2005). Chemical characterization of exopolysaccharides from antarctic marine bacteria. Microbial. Ecol. 49, 578.

Morbach, S., and Krämer, R. (2008). Environmental stress response of Corynebacterium glutamicum. In: A.Burkovski, Ed., Corynebacteria: Genomics and Molecular Biology. UK: Caister Academic Press, p. 313.

Nikolaev, Y.A. (2004). Extracellular factors of bacterial adaptation to unfavorable environmental conditions. Appl. Biochem. Microbiol. 40, 327.

Noghabi, K.A., Zahiri, H.S., and Yoon, S.C. (2007). The production of a cold-induced extracellular biopolymer by Pseudomonas fluorescens BM07 under various growth conditions and its role in heavy metals adsorption. Process Biochem. $42,847$.

Park, Y.-J., Ko, J.-J., Yun, S.-L., Lee, E.Y., Kim, S.-J., Kang, S.-W., Lee, B.-C., and Kim, S-K. (2008). Enhancement of bioremediation by Ralstonia sp. HM-1 in sediment polluted by $\mathrm{Cd}$ and Zn. Bioresource Technol. 99, 7458.

Saravanan, P., and Jayachandran, S. (2008). Preliminary characterization of exopolysaccharides produced by a marine biofilm-forming bacterium Pseudoalteromonas ruthenica (SBT 033). Lett. Appl. Microbiol. 46, 1.

Sauer, K., and Camper, A.K. (2001). Characterization of phenotypic changes in Pseudomonas putida response to surfaceassociated growth. J. Bacteriol. 183, 6579.

Sharma, S., Sundaram, C.S., Luthra, M., Singh, Y., Sirdeshmukh, R. and Gade, W.N. (2006). Role of proteins in resistance mechanism of Pseudomonas fluorescens against heavy metal induced stress with proteomics approach. J. Biotechnol. 126, 374 .

Sonawane, A., Klöppner, U., Hövel, S., Völker, U., and Röhm, K.H. (2003). Identification of Pseudomonas proteins coordinately induced by acidic amino acids and their amides: A two-dimensional electrophoresis study. Microbiology 149, 2909.

Srivastava, N.K., and Majumder, C.B. (2008). Novel biofiltration methods for the treatment of heavy metals from industrial wastewater. J. Hazard Mater. 151, 1.
Stockwell, V.O., and Loper, J.E. (2005). The sigma factor RpoS is required for stress tolerance and environmental fitness of Pseudomonas fluorescens Pf-5. Microbiology 151, 3001.

Teitzel, G.M., and Parsek, M.R. (2003). Heavy metal resistance of biofilm and planktonic Pseudomonas aeruginosa. Appl. Environ. Microbiol. 69, 2313.

Tom-Petersen, A., Hosbond, C., and Nybroe, O. (2001). Identification of copper-induced genes in Pseudomonas fluorescens and use of a reporter strain to monitor bioavailable copper in soil. FEMS Microbiol. Ecol. 38, 59.

Vasudevan, N., Bharathi, S., and Arulazhagan, P. (2007). Role of plasmid in the degradation of petroleum hydrocarbon by Pseudomonas fluorescens NS1. J. Environ. Sci. Heal. A 42, 1141.

Vilain, S., Cosette, P., Zimmerlin, I., Dupont, J.P., Junter, G.A., and Jouenne, T. (2004). Biofilm proteome: Homogeneity or versatility? J. Protein Res. 3, 132.

Wasi, S., Jeelani, G., and Ahmad, M. (2008). Biochemical characterization of a multiple heavy metal, pesticides and phenol resistant Pseudomonas strain. Chemosphere 71, 1348.

Wehmhöner, D., Häussler, S., Tümmler, B., Jänsch, L., Bredenbruch, F., Wehland, J., and Steinmetz, I. (2003). Inter- and intraclonal diversity of the Pseudomonas aeruginosa proteome manifests within the secretome. J. Bacteriol. 185, 5807.

Willcox, M.D.P., Harmis, N., Cowell, B.A., Williams, T., and Holden, B.A. (2001). Bacterial interactions with contact lenses; Effects of lens material, lens wear and microbial physiology. Biomaterials 22, 3235.

Zawadzka, A.M., Crawford, R.L., and Paszczynski, A.J. (2007). Pyridine-2,6-bis(thiocarboxylic acid) produced by Pseudomonas stutzeri $\mathrm{KC}$ reduces chromium(VI) and precipitates mercury, cadmium, lead and arsenic. Biometals 20, 145.

Zhang, Y.M., and Rock, C.O. (2008). Membrane lipid homeostasis in bacteria. Nat. Rev. Microbiol. 6, 222.

Zhou, F., Guo, H., and Liu, L. (2007a). Quantitative identification and source apportionment of anthropogenic heavy metals in marine sediment of Hong Kong. Environ. Geol. 53, 295.

Zhou, F., Guo, H., and Hao, Z. (2007b). Spatial distribution of heavy metals in Hong Kong's marine sediments and their human impacts: A GIS-based chemometric approach. Mar. Pollut. Bull. 54, 1372. 
